\title{
Notes on the vocalizations of Thick-billed Grasswren (Amytornis textilis)
}

Peter Boesman

In the following we briefly analyze and compare voice of the different races of Thick-billed Grasswren (Amytornis textilis). We also try to quantify the extent of any vocal differences using the criteria proposed by Tobias et al. (2010), as a support for taxonomic review. We have made use of sound recordings available on-line from Macaulay Library (ML).

There are very few recordings available, only of races textilis and modestus.

Song of both races starts with a few high-pitched 'tsee' notes which lead to a variable squeaky twittered phrase. The latter consists of several sharply descending or rising notes covering a wide frequency range, and occasionally also includes a fast and short high-pitched rattle (Fig. 1).

textilis (west)

intro notes

$\begin{array}{ll}\min \text { freq. } & 7000-7900 \mathrm{~Hz} \\ \max . \text { freq. } & 8800-9000 \mathrm{~Hz}\end{array}$

phrase

$\begin{array}{ll}\text { longest note } & 0.11-0.135 \mathrm{~s} \\ \text { min freq. } & 2200-3770 \mathrm{~Hz} \\ \text { max. freq. } & 13000-15600 \mathrm{~Hz}\end{array}$

modestus (east)

intro notes

$\begin{array}{ll}\min \text { freq. } & 7000-7100 \mathrm{~Hz} \\ \max . \text { freq. } & 8000-9000 \mathrm{~Hz}\end{array}$

phrase

$\begin{array}{ll}\text { longest note } & 0.085-0.095 \mathrm{~s} \\ \text { min freq. } & 2259-3700 \mathrm{~s} \\ \text { max. freq. } & 11000-13700 \mathrm{~Hz}\end{array}$

From the above, it would seem that there are no obvious differences among both races. There is a possibility that modestus has slightly shorter notes, and reaches slightly lower frequencies, but more samples would be needed to prove this, or any other vocal difference.

This note was finalized on 1st October 2015, using sound recordings available on-line at that moment. We would like to thank in particular the Macaulay Library for giving access to restricted recordings. 


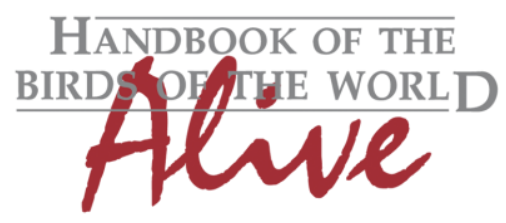

\section{ORNITHOLOGICAL NOTES}

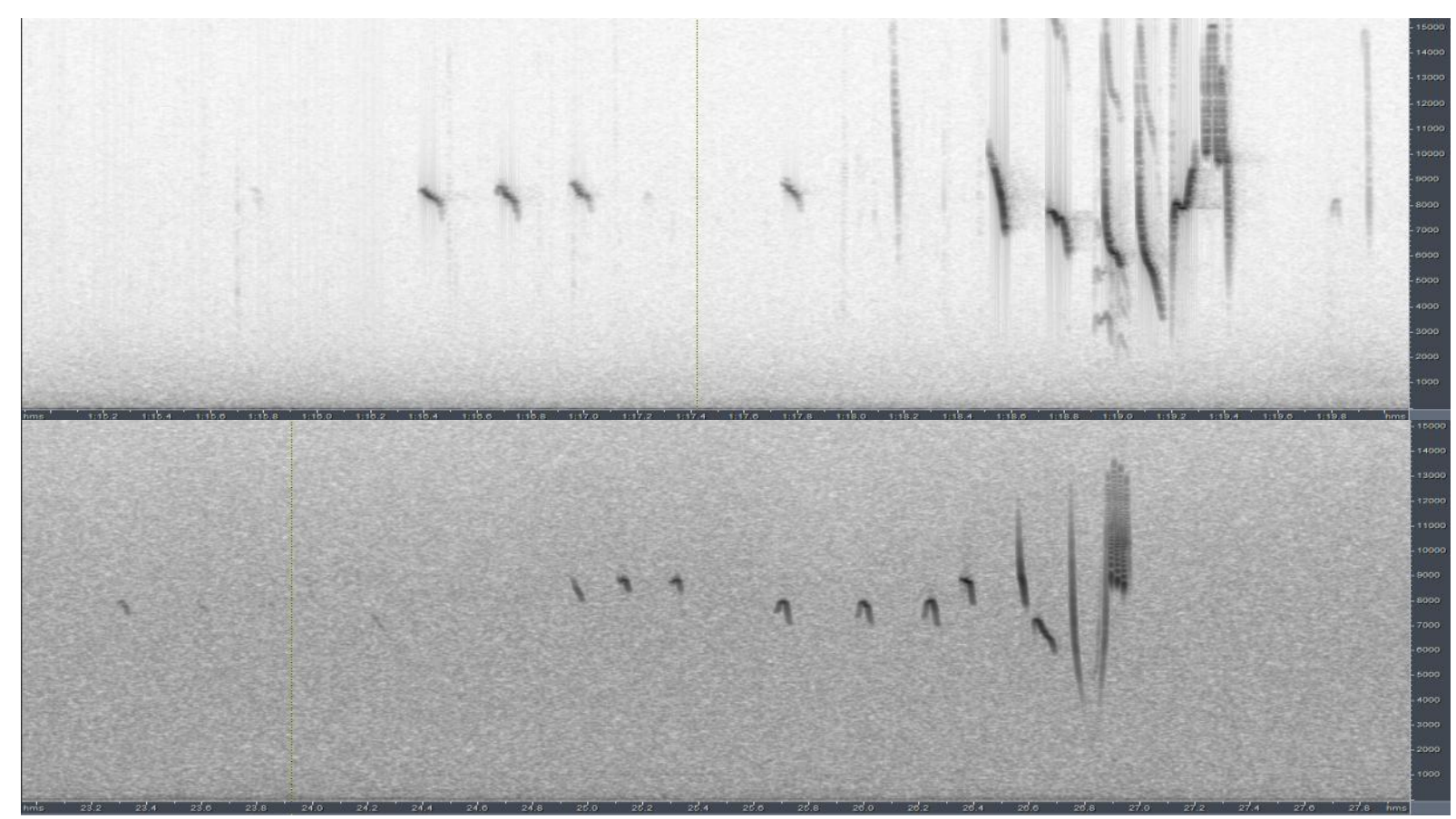

Figure 1: song of races textilis (West Australia)(top) and modestus (South Australia)(bottom)

\section{References}

Tobias, J.A., Seddon, N., Spottiswoode, C.N., Pilgrim, J.D., Fishpool, L.D.C. \& Collar, N.J. (2010). Quantitative criteria for species delimitation. Ibis 152(4): 724-746.

\section{Recommended citation}

Boesman, P. (2016). Notes on the vocalizations of Thick-billed Grasswren (Amytornis textilis). HBW Alive Ornithological Note 149. In: Handbook of the Birds of the World Alive. Lynx Edicions, Barcelona. (retrieved from http://www.hbw.com/node/932074 on 16 August 2016). 